\title{
New insights on the interface between metal oxide and biosystem
}

\author{
Walter Langel ${ }^{1 *}$, Susan Köppen², Wenke Friedrichs', Armin Marx¹, Bastian Ohler ${ }^{1}$ \\ From 9th German Conference on Chemoinformatics \\ Fulda, Germany. 10-12 November 2013
}

The interface between titanium dioxide and biological solution is relevant for the bioactivity of titanium implants. Adhesion phenomena between inorganic solids are of general interest for mineralization and bone formation processes.

Such interfaces are complex systems with many constituents including the hydroxylated metal oxide support, hydrocarbon contamination, ionic water solution and a variety of biopolymers. Our computational methods comprise classical molecular dynamics with around $10^{6}$ atoms in the 10-100 ns range and ab initio molecular dynamics wit 100-200 atoms for some ps.

- Electronic structure calculations show that even very thin layers of $\mathrm{TiO}^{2}$ on $\mathrm{Ti}$ metal may be commensurate and crystalline [1]. A variety of smooth and rough surfaces are implemented in force field simulations.

- The oxide is hydroxylated and its surface charge density correlates with the $\mathrm{pH}$-value. The highly hydrophilic $\mathrm{TiO}^{2}$ is in practice screened by hydrocarbons, which may enhance inflammatory complications of implants [2]. Simulations on the nature of this contamination are presented.

- Sequence specific protein adsorption on inorganic surfaces was found in several experiments on inorganic surfaces, even though no key-lock mechanism is conceivable. We propose two effects [3]: (i) Contacts of single amino acid side chains to local charges in the surface have rupture energies, which sensitively depend on the electrostatics. The adhesion of appropriate double contacts is very strong exceeding simple hydrogen bonding. (ii) Soft motifs of proteins easier attach to the surface than rigid helices or strands.

- Close to solids water has an ordered structure, which only slightly depends on the surface charge

* Correspondence: langel@uni-greifswald.de

${ }^{1}$ Institut für Biochemie, Universität Greifswald, 17487 Greifswald, Germany Full list of author information is available at the end of the article density. These layers hinder protein adsorption. A major difference to the bulk is the reduced water mobility there.

\section{Authors' details}

${ }^{1}$ Institut für Biochemie, Universität Greifswald, 17487 Greifswald, Germany. ${ }^{2}$ Hybrid Materials Interfaces Group, Faculty of Production Engineering University of Bremen, 28359 Bremen, Germany.

\section{Published: 11 March 2014}

\section{References}

1. Ohler B, Prada S, Pacchioni G, Langel W: DFT Simulations of Titanium Dioxide on Titanium Metal. J Phys Chem 2013, 117:358.

2. Ribiero M, Monteiro FJ, Ferraz MP: Infection of orthopaedic implants with emphasis on bacterial adhesion process and techniques use in studying bacterial-material interactions. Biomatter 2012, 2:176.

3. Friedrichs W, Ohler B, Langel W, Monti S, Köppen S: Adsorption of Collagen Nanofibrils on Rough TiO2: A Molecular Dynamics Study. Advanced Engineering Materials 2011, 13:B334.

\section{doi:10.1186/1758-2946-6-S1-O20}

Cite this article as: Langel et al:: New insights on the interface between metal oxide and biosystem. Journal of Cheminformatics 2014 6(Suppl 1): $\mathrm{O} 20$

\section{Publish with ChemistryCentral and every scientist can read your work free of charge \\ "Open access provides opportunities to our colleagues in other parts of the globe, by allowing anyone to view the content free of charge." \\ W. Jeffery Hurst, The Hershey Company. \\ - available free of charge to the entire scientific community \\ - peer reviewed and published immediately upon acceptance \\ - cited in PubMed and archived on PubMed Central \\ - yours - you keep the copyright \\ Submit your manuscript here: \\ http://www.chemistrycentral.com/manuscript/ ChemistryCentral}

